\title{
The impact of financial deepening on economic growth in Nigeria (1981-2018)
}

\author{
DIVINE CHINYERE SAMUEL-HOPE, OMANKHANLEN ALEXANDER \\ EHIMARE, GODSWILL OSAGIE OSUMA \\ Department of Banking and Finance, Covenant University ota, Ogun State, NIGERIA
}

\begin{abstract}
Different academics and experts have acknowledged that developing the financial sector positively impacts economic growth by increasing productivity, progress and national investment. Expanding the financial sector allows financial intermediaries to carry out functionalities of deploying, aggregating and directing a country's savings into an investment which contributes to domestic progression. This research explores the effect of financial deepening on Nigeria's growth for 38 years covering 1981- 2018. The main research goals were to investigate the linkages among time and savings deposit of commercial banks, money supply and credit to the private sector on the economy's growth. Data was obtained from CBN Bulletin different issues and analyzed using Autoregressive Distributed Lag. From the result of analysis, we found out that long run relationship existed but no regressor was found to be significant. Credit to the private sector to GDP was inversely related to GDP growth whereas money supply to GDP had positive relations with economic growth rate, time and savings deposits in commercial banks negatively affected national growth. Policies favoring credit lending to the private sector should be encouraged by stakeholders in the economy, for instance, higher savings interest rates would encourage more savings. More importantly, policies should be enacted to make sure that savings are transmitted into productive investments that can yield financial deepness. Keywords-Autoregressive Distributed Lag, Economic Growth, Financial deepening.
\end{abstract}

Received: August 16, 2020. Revised: December 18, 2020. Accepted: December 24, 2020. Published: December $27,2020$.

\section{Introduction}

Financial deepening is the method of developing and expanding financial institutions such as commercial banks, development finance institutions, discount houses, bureau-de-change, merchant banks, holding companies, stock markets, etc. It also relates to an enhancement in delivery of financial products and services at every societal phase with a wider selection [1]. In addition, Financial deepening can be regarded as a financial institution's capacity to efficiently and effectively channel savings for investment reasons.

Globally, the financial system has been recognized as playing a significant role in domestic advancement [2]. It constitutes a primary part of mobilizing and allocating resources for productive use, providing monetary management structures. The system's framework for managing liquidity improves the economic performance of the players by enhancing people's overall standard of living. It gives room for a more efficient transfer of resources.

For the preceding two decades, arguments on financial sector's complexity and national growth has been ongoing with literally two schools of thought. The first argues that financial deepening is constrained in supporting the progression of real activities [3], [4]. So, this perspective opines that domestic development induces financial growth. Robinson (1952) [4] states that finance follows where enterprises lead. The second school of thought, on the other hand, sees financial deepening as essential in propelling expansion operations, innovations and economic growth [5], [6], [7], [8]. Haber, North \& Weingast (2008) [9] states that economies do not possess diversified market securities and banking structures due to national prosperity, rather they are rich as a result of these sophisticated and robust banking securities robust.

The Nigerian financial system has experienced several modifications in recent years, beginning from 1986 when a series of reforms were implemented such as Structural Adjustment Programme. Before 1986 the economy was defined by extensive regulation, stifling of competition, misallocation of resources, poor banking structure, absence of adequate risk management mechanism, interest rate administration, direct credit program, absence of clear-cut activities, amongst other variables [10]. The purpose of this reform was to broaden financial schemes with the overall anticipation of increasing its activities.

Nigeria has experienced financial sector growth, and as a result, financial deepening has increased growth in 
the financial market over time, increases in stock and capital market operations, increased bank branches, fast use of debit and credit cards. Increased use of payment system such as POS (Point of Sale), ATM (Automatic Teller Machine), Electronic deposit transfer, expanded internet banking facilities, digital banking and increased total banking deposits.

\section{Statement of the Problem}

In the previous few decenniums, financial deepening has triggered massive focus from developmental finance professionals and has been argued substantially. This argument could be categorized into two key postulations: the supply and the demand leading hypothesis. Supply leading highlights financial deepening as important fundamentals for growth. Supply leading hypotheses infers that financial deepness fosters progressiveness. This hypothesis opposes that the presence of financial market produces and increases liquidity, mobilizes savings and engenders domestic progress [5]. According to Demand-leading hypothesis, financial deepening basically emanates from real sector advancement that can be assigned to greater relevant uses at preliminary growth stages [11]. This indicates that earlier endeavours to grow financial markets may cause resource misuse that would have been disbursed to higher priority intentions at prior development phases. National progressions bring about a greater demand for financial services, which triggers prominent monetary enlargement [3], [4].

Several steps have been taken by the monetary authorities in Nigeria since 1986 to deepen financial bodies and reduce the amount of associated financial constraints. Reformations of financial systems emanated in adaptations of Nigeria's financial structure in attempts to promote competitiveness, reinforce managerial responsibilities of administrative authorities, improve public-financial system relationship and reduce distortion in investment decisions. Many new financial instruments and methods were created and current ones altered, the financial markets have been adjusted to meet new requirements and conditions. These have been designed to deepen the financial system. But how have these impacted on Nigeria's growth? Therefore, given the preceding backdrop, this works intends to ascertain the influence of financial deepening on Nigeria's growth from 1981 to 2018.

\section{A. Research Questions}

In assessing this study's topic, these research inquisitions were projected:
1. To what magnitude does the money supply impact upon economic growth?

2. To what level has the credit to the private sector impacted economic growth?

3. How does savings and time deposit of commercial banks influence the Nigerian economic growth level?

\section{B. Objective of the Study}

This paper mainly targets to establish the effects of financial deepening on Nigeria's economic advancement. Specifically, this research aims to:

1. To investigate the influence of money supply on economic growth

2. To evaluate the impact of credit to the private sector on economic growth

3. To analyze the impact of savings and time deposit of commercial banks on Nigeria's economic growth levels.

\section{Research Hypotheses}

This work is structured to assess the impact of financial deepening on economic growth in Nigeria, hence, the following postulations:

1. Ho- money supply has no significant impact on economic growth in Nigeria

2. H1- credit to the private sector has no significant effect on Nigeria's development.

3. H2- savings and time deposit has no significant influence on Nigerian economic growth.

\section{Review of the Related Literature}

\section{Conceptual Framework}

\section{Financial Deepening}

Experts in economic development frequently use the concept of financial deepening which is the capacity of a financial institution to efficiently and effectually allocate savings for investment reasons [12]. Financial deepening implies the establishment and evolution of financial tools, markets and institutes, as well as enhancing the efficiency of financial activities that promote investment and progression [13].

According to Nnanna \& Dogo (1998) [14] and Nzotta (2004) [15], financial deepening encapsulates a larger proportion of money supply to Gross Domestic Product (M2/GDP) that subsequently assumes that higher availability of money liquidity within a country raises existent economic opportunities for continuous and 
stabilized increment.

Two fundamental measurable quantifiers are usually adopted to gauge the size of financial markets: intermediation ratio and monetary ratio. While the latter contains liquid liabilities or pecuniary-related measures such as broad money supply to GDP ratio. The intermediation ratio comprises of bank-dependent barometers such as credit to the private sector and savings to time deposit [16].

\section{Economic Growth}

This terminology represents the rise in real national income or gross domestic product (GDP). GDP can be estimated as the production value generated nationally or as the complete revenue gained in a nation including salaries, interests, rents and revenues. Iram \& Nishat (2009) [17] define economic growth as a gauge of an economy's health, and capital is one of the basic requirements for maintaining and boosting growth. The financial health of a country could be evaluated by considering national improvements. Economic growth is a determinant of a society's living standards.

\section{The link between Financial Deepening and Economic Growth}

Literature has revealed conflicting results about this relationship, with conventional supply side trends dominating as financial sector development was anticipated to occur before that of the real economic sector growth. This constitutes one perspective to this relationship and is broadly propagated by King \& Levine (1993) [18], McKinnon (1973) [6] and Shaw (1973) [19]. Also, Odhiambo (2011) [11] recognizes related empirical studies in developing nations to include Suleiman \& Abu-Qaun (2008) [20], Bhattacharya \& Sivasubramanian (2003) [21], Xu (2000) [22], Ghali (1999) [23], Darrat (1999) [24], De Gregoria \& Guidotti (1995) [25] and Jung (1986) [26]. The second angle posits that economic growth induces enhancement of the financial market (demand-side) [11, 27]. Lastly, some authors have illustrated that national growth and financial progression can granger cause each other [11], [28], [29], [30].

Notwithstanding, one common thing that can be deduced from all these views is that financial development positively benefits community growth via the crucial role of monetary intermediaries. So, higher availability of institutions and financial instruments lessens operational and information costs.

\section{E. Theoretical Review}

Three theories are used as a hypothetical basis to explain the connection between financial deepening and economic growth. These theories include financial deepening theory, theory of financial intermediation, and endogenous growth model, which are discussed below.

\section{Financial Deepening Theory}

Ohwofasa \& Aiyedogbon (2013) [31] opine that the magnitude of financial deepening shows how sound a financial is with its capability of creating credits relating to deposit and lending rates. Hence, this theory elucidates the positive influence of financial system on national development through voluminous sectoral activities.

\section{Theory of Financial Intermediation}

This theory suggests that financial intermediaries are very important in growth processes via transference of finances from net savers (surplus units) to net borrowers (deficit units), which influences investment and propels growth. Here, market failure of information asymmetry can be conquered through transformation of risk features of assets. Such credit market asymmetry is due to the fact that borrowers typically have more knowledge about their investment schemes (moral integrity, industriousness and collateral) than the lenders.

Schumpeter (1911) [7] advocates that sufficiently functional financial intermediaries can enhance general economic efficacy via allocating and pooling finances to advance innovation and entrepreneurship which are essential for developing an economy. Gurley \& Shaw (1960) [32] opine that financial intermediaries are chances to boost financial capacity (investment and savings) of a lender. Therefore, higher intermediation aids greater savings mobilization, consequently enhancing investment and growth levels [33].

\section{Endogenous Growth Model}

Mediums through which financial firms impact longterm economic growth was first proposed by Levine (1991) [5] and Bencivenga \& Smith (1991) [34], which provided direct and indirect linkage. This is founded on the ideology that growth outcomes are connected to income distribution, financial and technological upgrades. Hence, the link between long run societal growth and financial advancement is stressed by productivity growth as associated with growth, investments, savings and financial markets. King \& Levine (1993) [18] concentrates on connectivity among economic growth and entrepreneurship, thereby financial institutions are key in funding and monitoring talented entrepreneurs in innovative operations and new 
commodity launching.

\section{Empirical Review}

Nwaolisa \& Cyril (2019) [35] examined effects of financial deepening (market capitalisation, private sector credit and money supply) on Nigerian economy from 1990 to 2016 using ordinary least square (OLS) to analyse data from National Bureau of Statistics (NBS) and Central Bank of Nigeria (CBN) statistical bulletin. All three variables were established to positively affect Nigeria's financial deepening. Thus, suggestions were proffered which revolved around practitioners attempt to minimise liquidity barriers within stock markets, lifting constraints in international markets and aiding market entry while also lessening rampant cases of unproductive credits, such that private sector loans are optimized in real economic sectors. It was likewise recommended that policies surrounding higher flows of investible funds and improved banking capacity in lending credits would increase impacts of private sector and broad money supply in Nigeria.

Herman \& Klemm (2019) [36] examined financial deepening effects in Mexico from 2007 to 2015 through disequilibrium regression approach. The study discovered that supply influences are specifically vital in determining Mexican loans. Contemporary policies tackle most supply limitations although their degree of successful outcomes is contingent upon proper enactment. The major issue future-wise is with facilitating financial deepening and simultaneously restricting the riskiness of monetary stabilization.

Vipin \& Arvind (2015) [37] researched on the dimension to which financial deepening affects India's growth from 1990-2014. Autoregressive distributed lag and bound test was utilized to analyse the long-term relations between the variables. Granger Error Correction Model (ECM) approach was also implemented to approximate short-run causal effect. Results imply that long run equilibrium connection is existent. Additionally, financial deepness was seen to trigger national growth both on short and long run basis. Thus, it was inferred that governmental bodies must consciously endeavor to enhance financial deepening so as to spur societal progression. Specialized attempts should be made to supply stress-free lending to private enterprises, advancing stock markets and fostering international trade.

Bakang (2015) [33] explored financial deepening impacts on Kenya's banking sector through quarterly data between 2000 and 2013. Commercial bank deposits (CBD) as a share of nominal GDP; Commercial bank assets (CBA) as a proportion of CBA plus central bank assets (CCBA); CPS as a portion of nominal GDP; and liquid liabilities (LL) as ratio to nominal GDP captured financial deepening. Since all variable were stationary at first difference, Johansen Jeluisus cointegration was employed to reveal the existence of cointegrating equations. Kenya's banking sector was found to be critical to its growth with all four (4) independent variables having statistically significant and positive effects on GDP. Thus, it was proposed that existent policies to incentivize public savings with commercial banks should be reinforced. The higher interest rate for depositors will be one attraction, moreover, financial inclusion policies should be intensified by greater utilisation and accessibility to formal banking services while simultaneously lessening bank transaction costs.

Adu, Marbuah \& Mensah (2013) [38] researched long run influences of financial deepening on Ghanaian economy via dataset from 1998 to 2011. Private sector credit ratio to GDP, total domestic credit ration, aggregate bank liabilities ratio, money supply ratio to GDP were utilized in measuring financial deepening with control variables of real gross government expenditure, trade openness and inflation rate. Despite using several variables measures, the observation/data time frame is inadequate to yield statistically significance for each variable, and this questions their findings, which could be spurious as a result

Onwumere, Ibe, Ozoh \& Mounanu (2012) [39] explored financial deepening influences on Nigeria's growth from 1992 to 2008 using supply-leading hypothesis and variables of broad money velocity, money stock diversity, market liquidity, economic volatility and market capitalization. It was affirmed that market liquidity and broad money velocity aid Nigerian growth whereas market capitalisation, economic volatility and money stock diversification had reverse effects. Therefore, it was proffered that government policies should aim to increase money supply and boost efficient capital markets for general economic effectiveness, creation and expansion of liquidity, savings mobilization, higher capital accumulation and greater transferred finances from stereotyped to growthstimulating industries.

Unalmis (2002) [40] assesses the causal direction between financial expansion and national growth in Turkey through granger within vector error correction model (VECM). It was affirmed that bidirectional causality is prevalent for variables studied on a longterm basis. 


\section{Methodology}

In this part of the research, the connectivity between financial deepening and economic growth in Nigeria was examined. The former was interpreted as the ratio of money supply to GDP, the ratio of private sector credit to GDP, and the ratio of saving and time deposit. The data utilized here are annual time series data of relevant variables which are mainly secondary and collated from CBN Statistical Bulletin while Autoregressive Distributed Lag was adopted.

\section{F. Model Specification}

The general form for Autoregressive Distributed Lag is given in the form below:

$\mathrm{GDPt}=\mathrm{f}(\mathrm{FDt})$

$\mathrm{FDt}=(\mathrm{MSGt}, \mathrm{PCGt}, \mathrm{STDt})$

Where:

GDPt $=$ Gross Domestic Product

$\mathrm{FDt}=$ Financial Deepening

MSGt $=$ Money supply/GDP ratio (M2/GDP)

PCGt $=$ Ratio of Private Sector Credit to GDP (PSC/GDP)

$\mathrm{STD} t=$ Savings and Time Deposit

\section{G. Bounds test}

The null hypothesis suggests that no long run relationship exists when the estimated F-statistics value is less than the lower bound critical values, $\mathrm{I}(0)$ and the I(1) critical bound which reveals no long-run correlation between the regressand and regressors. Consequently, bounds test indicates that co-integration (long run connectivity) exists amongst variables.

$\triangle G D P R_{t}=\beta_{0+} \Sigma_{j=1}^{p} \Phi_{j} \Delta G D P R_{t-j}+\sum_{j=0}^{p} \theta_{j} \Delta C P S \_G D P_{t-j}$ $+\sum_{j=0}^{p} \lambda j \Delta M 2_{-}$GDPt-j $+\sum_{j=0}^{p} \alpha_{j} \Delta S T D C O M M_{t-j}+$ $\delta_{1} G D P R_{t-1}+\delta_{2} C P S S_{-} G D P_{t-1}+\delta_{3} M 2_{-} G D P_{t-1}+$ $\delta_{4} S T D C O M M_{t-1}+\varepsilon_{t}$

Where $\Delta=$ first-difference operator; $p=$ maximum lag order. Existence of long run relationship is tested through F-statistics. The coefficient $(\boldsymbol{\Phi}, \boldsymbol{\theta}, \boldsymbol{\lambda}, \beta, \alpha)$ corresponds with short-run model dynamics, while $\left(\delta_{1}\right.$, $\delta_{2}, \delta_{3}, \delta_{4}$, ) represents the long-run relationship.

$\mathrm{H}_{0}: \delta_{1}=\delta_{2}=\delta_{3}=\delta_{4}=0$ (null, i.e. the long-run relationship does not exist)

$\mathrm{H}_{1}: \delta_{1} \neq \delta_{2} \neq \delta_{3} \neq \delta_{4} \neq 0$ (Alternative, i.e. the long-run relationship exists)

Given that co-integration exists, hence we estimate the coefficient of the long run model, whose specification is shown below,

$\triangle G D P R_{t}=\beta_{0}+\delta_{1} G D P R_{t-1}+\delta_{2} C P S_{-} G D P_{t-1}+$ $\delta_{3} M 2_{-} G D P_{t-1}+\delta_{4} S T D C O M M_{t-1}+\varepsilon_{t}$
Liew (2004), in other to specify the right ARDL Model, appropriate lag selection criterion such as AIC should be used provided the sample size is less than 60 . Given that the study used annual data, 2 is the maximum lag (p) that should be selected [41].

In conclusion, all the short-run coefficient model are coefficients that justify short-term dynamism which shows the meeting point of this model to ( $\partial$ ) and represents the re-parameterization of errors produced in one period and rectified in the next period.

\section{Estimation of the Results and Discussion}

In an attempt to verify the stationarity of variables, Augmented Dickey Fuller (ADF) t- statistics were employed to be sure of non-existence of seconddifferenced variable which makes bound tests result unreliable since they are based on the criteria of stationarity at level and/or at first difference. Table I shows the result of ADF test. Variable-stationarity is stationary when ADF t-stat is above its critical values at $5 \%$ significance. It is non stationary when ADF t-stat is below critical values at $5 \%$ significance.

ADF unit root test shows that the model's variables are $\mathrm{I}(0)$ and $\mathrm{I}(1)$, thus, the usage of Autoregressive Distributed Lag is being justified.

ARDL or bound test procedure would be embarked upon to ascertain the influence of financial deepening on national growth. Such technique is used when variables are stationary at levels and first difference i.e. combining both $\mathrm{I}(0)$ and $\mathrm{I}(1)$.

Narayan (2005) [42] stated that existing critical values in Pesaran F-statistics is not applicable. Hence, providing a collection of critical values for a sample size from 30 to 80 . The approximated F-stat (5.177132) is above the upper bound value at 10,5 and 1 percent. Consequently, $\mathrm{H} 0$ is rejected and concludes that longrun correlation is existent between the influences of financial deepening on Nigeria's growth.

Table III reflects long-term coefficient among independent variables following the specified ARDL model. Outcomes depict that the regressors are not statistically significant. The coefficient estimates indicate that a 1 percent rise in credit to the private sector to GDP will induce about a .57 percentage decline in GDP growth rate. Also, a 1 percent increment in money supply to gross domestic product will engender about 1.627 percentage rise in GDP growth. This does not conform to theory as financial deepening indicators 
are supposed to influence national growth levels positively. The coefficient of savings and time deposits in commercial banks reveals that a 1 percent rise will lead to .000631 percent fall in economic growth. This result infers that $\mathrm{H} 0$ will be accepted and $\mathrm{H} 1$ is rejected.

Table 4, shows the model's short-run dynamism. ECM indicates the rapidness of adjustment of errors that occurred in a given period is adjusted in the next period. Rule of thumb asserts that ECM or CointEq (-1) should be negatively signed between 0 and 1 . This result shows the coefficient of ECM is $(-0.78455)$. This shows that about 78.45 percent of errors that occur in one period are instantaneously amended subsequently. A good ARDL model specification shows the parameter stability, this is an econometric requirement suggested by [43]. The lag value of the independent variable GDPR is statistically significant at 1 percent and implies that there is an inverse relationship on short-term basis whereas all regressors in the short run are statistically insignificant.

\begin{tabular}{|c|c|c|c|c|c|c|c|}
\hline Variables & Test statistics & Critical Value & Remark & Test Statistics & Critical Value & Remark & $\begin{array}{c}\text { Order of } \\
\text { integration }\end{array}$ \\
\hline CPS_GDP & -0.856241 & -2.943427 & Non stationary & -4.876972 & -2.945842 & Stationary & I(1) \\
\hline GDPR & $\mathbf{- 4 . 9 5 9 6 0 5}$ & $\mathbf{- 2 . 9 4 3 4 2 7}$ & Stationary & n.a & n.a & n.a & I(0) \\
\hline M2_GDP & -1.072075 & $\mathbf{- 2 . 9 4 3 4 2 7}$ & Non Stationary & $\mathbf{- 5 . 6 4 3 0 6 2}$ & $\mathbf{- 2 . 9 4 5 8 4 2}$ & stationary & I(1) \\
\hline
\end{tabular}

Table II ARDL Bound Test or Test for Co-integration

\begin{tabular}{|c|c|c|c|c|}
\hline Test statistic & Value & Significance level (\%) & & Critical value bound \\
\hline F-statistic & 5.177132 & & $\mathrm{I}(0)$ & $\mathrm{I}(1)$ \\
\hline & & 1 & 4.31 & 5.544 \\
\hline & & 5 & 3.1 & 4.088 \\
\hline & & 10 & 2.592 & 3.454 \\
\hline
\end{tabular}

Source: E-views10 output

Note: Based on Narayan (2005) [42]

Table III Long-run Coefficient

\begin{tabular}{|c|c|c|c|c|}
\hline $\begin{array}{c}\text { AIC - ARDL (1,0,1,0) } \\
\text { Dependent variable GDPR }\end{array}$ & Coefficient & SE & T-statistics \\
\hline CPS_GDP & -0.571871 & 1.168141 & -0.489557 \\
\hline M2_GDP & 1.627016 & 1.394756 & 1.166524 & 0.6279 \\
\hline STDCOMM & -0.000631 & 0.000796 & -0.792774 & 0.2523 \\
\hline
\end{tabular}

Source: E-views10 output

Note: they are significant at 5\% level

Table IV Short-run Coefficient or ECM

\begin{tabular}{|c|c|c|c|c|}
\hline $\begin{array}{c}\text { AIC - ARDL (1,0,1,0) } \\
\text { Dependent variable GDPR }\end{array}$ & Coefficient & SE & T-statistics \\
\hline GDPR(-1)* & -0.784550 & .156656 & -5.008093 & $.0000^{*}$ \\
\hline CPS_GDP** & -0.448662 & .918882 & -0.488269 & .6288 \\
\hline M2_GDP(-1) & 1.276476 & 1.107674 & .152393 & .0 .794474 \\
\hline STDCOMM** & -0.000495 & .000623 & .9088 & .4330 \\
\hline D(M2_GDP) & .9088 & .9088 & -0.115491 & 0.0000 \\
\hline ECM & -0.784550 & 0.145124 & \\
\hline
\end{tabular}

Source: E-views output

Note: "D" represents difference, * significance at 1 per cent. 


\section{H. Parameter stability test}

From Fig. 1 it is observed that the cumulative sum (CUSUM) test is in-between the critical boundaries at 5 percent. Hence, it concludes that ARDL indicates stable parameters.

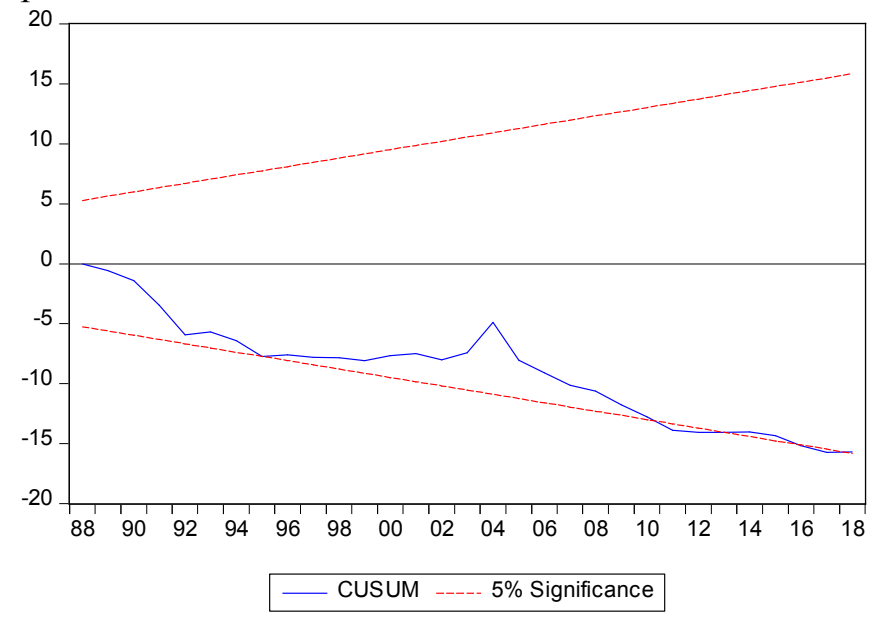

Fig. 1 The cumulative sum (CUSUM) test

\section{Post Estimation test}

Table $\mathrm{V}$ displayed other diagnostic tests and found that serial correlation is non-existent and disturbances variables are homoscedastic.

Table V Other diagnostic tests

Breusch-Godfrey Serial Correlation LM Test:

\begin{tabular}{llll}
\hline \hline F-statistic & .508823 & Prob. F(2,29) & .6065 \\
Obs*R-squared & 1.254359 & Prob. Chi-Square(2) & .5341 \\
\hline \hline
\end{tabular}

Heteroskedasticity Test: Breusch-Pagan-Godfrey

\begin{tabular}{lrl}
\hline \hline F-statistic & 1.322558 Prob. F(5,31) & .2804 \\
Obs*R-squared & 6.505054 Prob. Chi-Square(5) & .2601 \\
Scaled explained & \\
SS & 15.34265 Prob. Chi-Square(5) & .0090 \\
\hline \hline
\end{tabular}

\section{Conclusion and Recommendation}

This paper intended to analyze the influences of financial deepening on Nigeria's growth. Key objectives were to ascertain the relationship between money supply to GDP and economic growth; impact of credit to the private sector to GDP on economic growth; and effects of time deposit and savings of commercial banks on Nigerian growth. In part 2, literature was reviewed on conceptual issues of financial deepening and economic growth as well as their linkages. Afterward, various theories including supply leading and demand following hypothesis, financial deepening theory, the theory of financial intermediation and endogenous growth model (an extension of the exogenous model, which is, in turn, a build-up of Harrod-Domar model). Empirical works were reviewed of which both negative and positive relationships were discovered for different measures of financial deepening and GDP. The third section introduced the methodology which constituted yearly time series secondary data from CBN Statistics.

Due to the mixed order of stationarity at levels and first difference, Autoregressive Distributed Lag was employed. Long run relationship existed for the model but no regressor was found to be significant. Credit to private sector to GDP had negative relations with GDP growth, money supply to GDP also had a negative relationship to the economic growth rate. These findings were not aligned with theoretical expectations of positively impacting the Nigerian economy, possibly because the depth of national financial deepness is insufficient. Similarly, time and savings deposits in commercial banks negatively affected national growth. Hence, the null hypothesis for all scenarios will be accepted while the alternative is accepted. However, the ECM indicates that about 78.45 percent of errors which occurred in one period will be automatically remedied in forthcoming periods annually. Parameter stability reflects the lag value of GDPR as statistically significant at 1 percent, thereby implying an inverse relationship in the short run whereas all explanatory variables in the short run are statistically insignificant. Also, cumulative sum (CUSUM) test was in-between critical boundaries at 5 percent. Hence, ARDL co-integration shows stabilized parameters. Other diagnostic tests revealed non-existence of serial correlation and are homoscedastic disturbances variables.

Policies favoring credit lending to the private sector should be encouraged by Nigerian economy, for instance, higher lending interest rates would encourage savings. More importantly, policies should be enacted to make sure that savings are transmitted into productive investments that can yield financial deepening. Savings and time deposits should also be encouraged in commercial banks to motivate cashless banking and economy. This will aid financial intermediation that will eventually translate into economic growth. 
APPENDIX

\begin{tabular}{|c|c|c|c|c|}
\hline year & STDcomm & GDPR & $\mathrm{M} 2 / \mathrm{gdp}$ & CPS/gdp \\
\hline 1981 & 5.80 & -13.12788 & 9.99 & 5.92 \\
\hline 1982 & 6.34 & -1.0531861 & 10.19 & 6.88 \\
\hline 1983 & 8.08 & -5.0504511 & 10.85 & 7.16 \\
\hline 1984 & 9.39 & -2.0215376 & 11.80 & 7.31 \\
\hline 1985 & 10.55 & 8.3228297 & 11.60 & 6.80 \\
\hline 1986 & 11.49 & -8.754177 & 11.76 & 7.53 \\
\hline 1987 & 15.09 & -10.7517 & 11.05 & 8.45 \\
\hline 1988 & 18.40 & 7.54252203 & 11.97 & 8.53 \\
\hline 1989 & 17.81 & 6.46719114 & 10.95 & 7.25 \\
\hline 1990 & 23.14 & 12.7660092 & 9.49 & 6.71 \\
\hline 1991 & 30.36 & -0.6178506 & 12.65 & 6.94 \\
\hline 1992 & 43.44 & 0.43372536 & 12.21 & 6.39 \\
\hline 1993 & 60.90 & 2.0903778 & 13.13 & 10.10 \\
\hline 1994 & 76.13 & 0.90976334 & 13.06 & 8.14 \\
\hline 1995 & 93.33 & -0.307469 & 9.99 & 6.22 \\
\hline 1996 & 115.35 & 4.99370554 & 9.15 & 6.31 \\
\hline 1997 & 154.06 & 2.80225644 & 10.05 & 7.69 \\
\hline 1998 & 161.93 & 2.71564018 & 10.64 & 7.67 \\
\hline 1999 & 241.60 & 0.47423758 & 11.85 & 8.12 \\
\hline 2000 & 343.17 & 5.31809338 & 12.74 & 7.69 \\
\hline 2001 & 451.96 & 4.4110652 & 15.60 & 9.40 \\
\hline 2002 & 556.01 & 3.78464818 & 13.29 & 8.21 \\
\hline 2003 & 655.74 & 10.3541846 & 14.68 & 8.24 \\
\hline 2004 & 797.52 & 33.735775 & 12.31 & 8.21 \\
\hline 2005 & $1,316.96$ & 3.44466681 & 11.85 & 8.26 \\
\hline 2006 & $1,739.64$ & 8.21096486 & 13.25 & 7.99 \\
\hline 2007 & $2,693.55$ & 6.82839835 & 15.54 & 11.12 \\
\hline 2008 & $4,118.17$ & 6.2702637 & 20.45 & 17.67 \\
\hline 2009 & $5,763.51$ & 6.934416 & 21.25 & 20.55 \\
\hline 2010 & $5,954.26$ & 7.83973948 & 20.21 & 18.60 \\
\hline 2011 & $6,531.91$ & 4.887386661 & 19.33 & 16.93 \\
\hline 2012 & $8,062.10$ & 4.27927731 & 19.37 & 20.43 \\
\hline 2013 & $8,606.61$ & 5.39441631 & 18.92 & 19.67 \\
\hline 2014 & $11,936.93$ & 6.3097186 & 18.24 & 19.24 \\
\hline 2015 & $11,403.22$ & 2.65269329 & 19.68 & 19.84 \\
\hline 2016 & $12,146.91$ & -1.6168689 & 21.31 & 20.77 \\
\hline 2017 & $12,758.16$ & 0.81454403 & 19.67 & 19.43 \\
\hline 2018 & $14,822.20$ & 1.93 & 19.63 & 17.63 \\
\hline
\end{tabular}

STDcomm stands for savings and time deposit of commercial banks. It is also known as fixed deposit. It is the amount of money that is invested at an agreed interest rate over a specified period of time. It is the liability of a c commercial bank.

CPS/gdp stands for the credit to the private sector. it refers to the financial resources provided to the private sector by financial institution such as loan.

M2/gdp stands for money supply. It refers to the total money available in an economy at a particular time.
GDPR stands GDP growth rate, it measures how fast the economy is growing. It does this by comparing one quarter of the country's gross domestic product to the previous quarter.

\section{References}

[1] F. G. Sackey, E. M. Nkurumah, "Financial sector deepening and economic growth in Ghana," Journal of Economic and Sustainable Development, 3(8), pp. 122-140, 2012.

[2] L. S. Sanusi, "Developments in the Banking System in Nigeria," An Address Delivered on August 14th, 2009.

[3] R. E. Lucas, "On the Mechanics of Economic Development," Journal of Monetary Economics, No. 22, pp. 3-42, 1988.

[4] J. Robinson, "The Generalization of the General Theory," In the Rate of Interest and other Essays, London: Macmillan, 1952.

[5] R. Levine, "Financial development and economic growth: Views and agenda," Policy research working paper, World Bank, Washington, 1996.

[6] R. I. McKinnon, "Money and Capital in Economic Development," DC: Brookings Institution, Washington, 1973.

[7] J. Schumpeter, "The Theory of Economic Development," Cambridge Harvard University Press, 1911.

[8] W. Bagehot, "Lombard Street," Homewood, IL: Richard D. Irwin, 1873.

[9] S. H. Haber, D. C. North, R. B. Weingast, "Political Institutions and Financial Development," Stanford University Press, 2008.

[10] A. S. Otieno, "Financial deepening and profitability of commercial banks in Kenya," University of Nairobi, 2013

[11] M. Odhiambo, "Financial Intermediaries versus Financial Markets: A South African Experience," International Business and Economic Research Journal, 10 (2), 2011.

[12] S. M. Nzotta, E. J. Okereke, "Financial Deepening and Economic Development in Nigeria: An Empirical Investigation," African Journal of Accounting, Economics, Finance and Banking Research, 5(5), pp. 52-66, 2009.

[13] Ozturk, I et'al, "Finance - Growth Nexus: Evidence from Turkey," International Research Journal of Finance and Economics, 11, pp. 30-40, 2007.

[14] O. J. Nnanna, M. Dogo, "Structural Reform, Monetary Policy and Financial Deepening: The 
Nigerian Experience," Economic and Financial Review, 36(2), pp. 1-29, 1998.

[15] S. M. Nzotta, "Money, Banking and Finance, Theory and Practice Owerri," Hudson Jude Publishers, 2004.

[16] J. E. U. Ndebbio, "Financial Deepening, Economic Growth and Development: Evidence from Selected sub- Saharan African Countries," African Economic Research Consortium (AERC), Research Paper 142, Nairobi, August 2004.

[17] S. Iram, M. Nishat, "Sector level analysis of FDIgrowth nexus: A case study of Pakistan" The Pakistan Development Review, 48(4), pp. 875-882, 2009.

[18] R. G. King, R. Levine, "Finance, entrepreneurship and growth: Theory and evidence," Journal of Monetary Economics, 32(3), pp. 513-542, 1993.

[19]E. Shaw, "Financial Deepening in Economic Development,". London, Oxford University Press, 1973.

[20] A. Suleiman, A. Abu-Qaun, "Financial development and economic growth: Time-series evidence from Egypt," Journal of Policy Modelling, 30(5), pp. 887898, 2008.

[21] P. Bhattacharya, M. Sivasubramanian, "Financial development and economic growth in India: 19701971 to 1998-1999," Applied Financial Economics, 13(12), pp. 925-929, 2003.

[22] Z. Xu, " Financial development, investment and economic growth," Economic Inquiry, 38 (2), pp. $331-344,2000$.

[23] K. H. Ghali, "Financial development and economic growth: The Tunisian experience," Review of Development Economics, 3(3), pp. 310-322, 1999.

[24]A. F. Darrat, "Are financial deepening and economic growth causally related? Another look at the evidence," International Economic Journal, 13(3), pp. 19-35, 1999.

[25] J. De-Gregorio, P. Guidotti, "Financial development and economic growth," World Development, 23 (3), pp. 433-448, 1995.

[26] W. S. Jung, "Financial Development and Economic Growth: International Evidence," Economic Development and Cultural Change, 34(2), pp. 333346, 1986.

[27] C. Waqabaca, "Financial Development and Economic Growth in Fiji," Economics Department, Reserve Bank of Fiji, Working Paper2004/03 (December), 2004.

[28] R. Luintel, M. Khan, “A quantitative re-assessment of the finance-growth nexus: Evidence from a multivariate VAR," Journal of Development Economics, 60, pp. 381-405, 1999.

[29] P. O. Demetriades, K. A. Hussein, "Does financial development cause economic growth? Time series evidence from 16 countries," Journal of Development Economics, 51, pp. 387-411, 1996.

[30] A. Wood, "Financial development and economic growth in Barbados: Causal evidence," Savings and Development, 17(4), pp. 379-389, 1993.

[31]B. O. Ohwofasa, J. O. Aiyedogbon, “ Financial deepening and economic growth in Nigeria, 19862011: an empirical investigation," Journal of Economics and Development Studies, 1(1), pp. 2442, June 2013.

[32] J. G. Gurley, E. S. Shaw, "Financial Structure and Economic Development," Economic Development and Cultural Change, 15(3), pp. 257-268, 1967.

[33] M. L. N. Bakang, "Effects of financial deepening on economic growth in Kenya," International Journal of Business and Commerce, 4(7), pp. 1-50, 2015.

[34] V. R. Bencivenga, B. D. Smith, "Financial intermediation and endogenous growth," Review of Economic Studies, 58(2), pp. 403-444, 1991.

[35] E. F. Nwaolisa, U. M. Cyril, "Assessment of Financial Deepening on the Growth of Nigerian Economy: 1990-2016," Journal of Contemporary Research in Business, Economics and Finance, 1(1), pp. 16-29, 2019.

[36] A. Herman, A. Klemm, "Financial deepening in Mexico," The Journal of Banking and Financial Economics 1(11)2019, pp. 5-18, 2019.

[37] Vipin Ghildiya, A. K Pokhriyal, Arvind Mohan, "Impact Of Financial Deepening On Economic Growth In Indian Perspective: ARDL bound testing approach to cointegration," Asian Development Policy Review, 3(3), pp 49-60, 2015.

[38] G. Adu, G. Marbuah, J. T. Mensah, "Financial development and Economic Growth in Ghana: Does the measure of financial development matter," The Journal of Development Finance, 3, pp. 192-203, 2013

[39] J. Onwumere, I. G. Ibe, F. O. Ozoh, O. Mounanu, "The Impact of Financial Deepening on Economic Growth: Evidence from Nigeria," Research Journal of Finance and Accounting, 3(10), 2012.

[40]D. Ünalmiş, "The Causality between Financial Development and Economic Growth. The Case of Turkey," Research Department, Central Bank of the Republic of Turkey, 06100, Ankara, 2002. 
[41] M. Pesaran, Y. Shin, R. Smith, "Bounds testing approaches to the analysis of level relationships," Journal of Applied Econometrics, 16 (3), pp. 289326, 2001.

[42] P. K. Narayan, "Reformulating critical values for the bounds f-statistics approach to co-integration: an application to the tourism demand model for Fiji," Discussion papers, Department of Economics, Monash University, Clayton, 2004.

[43] V. N. Murthy, A. A. Okunade, "Determinants of US health expenditure: evidence from Autoregressive Distributed Lag (ARDL) approach to cointegration," Economic Modelling, 59(C), pp. 67-73, 2016.
Creative Commons Attribution License 4.0 (Attribution 4.0 International, CC BY 4.0)

This article is published under the terms of the Creative Commons Attribution License 4.0

https://creativecommons.org/licenses/by/4.0/deed.en_US 